組織 $=$ 可成著明ナル變性 ヨ來タセルト同時二。 左右內耳 $ᄏ$ 比較スレパ，大多數二極メテ顯著ナ ル差異フ認ムルノデアル。 先ヅ「コルチ」器二於テハ迷路全轘习檢シタル

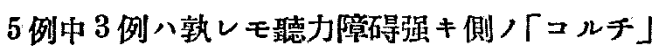
器八. 各迴轉及ハ一部迴轉二於テ 毛細胞八全 ク消失シテ原形フ留メザルカ 又八核八殘骸, ミア留メ.ダィテル氏細胞. ヘンゼン氏細胞. 支柱細胞. クラウヂゥス細胞等モ亦强ク變化シ テ.「トンネル」腔ハ全り消失シ.「コルチ」器 八個有ノ形ョ失ツテ僅カ二丘狀ノ變性七几細胞 !塊リトナリテ存スルニ反シ. 他側ノ「コルチ」 器ハ殆ンド正常二近キ形態习保ツテキル（寫鿓 供覽)。

次二胍絡带二於ケル變化モ亦甚ダ注目スベキモ ノが有り。迷路全䯣习检シタル5 例中 2 例二於 テハ「コルチ」器ノ變化ノ外.一一側ノ脈絡帶上皮 八著シク董脹膨化シ．ライスネル膜八强ク舉上 セラル、ニ反シ。他側ノ上皮八變化少ク－ライ スネル膜八正常位＝存スルラ知ル(寫資供覽). 神經篩細胞二於ケル䌡化モ亦著明ニシテ．特ニ 田中氏法ニヨレルモノ八勿諭。迷路全骼標本二 於テモ亦著明ナル變化 7 認メ. 且ツ左右二著シ 1 美異ノ存スル事ヨ知ル。

次二全ク㯖力シ認メザルニ至りタル3例中. 迷 路全䯠ヨ检シタル 2 例二於テハ蝸牛，膜溙部 $=$ 八左右共二極メテ高度ナル變化 一ハ「コルチ」器ニ。一八眽絡带ガ左右共㱠ン ド原形ラ留メザル迄二破壞サレテキルノデフ

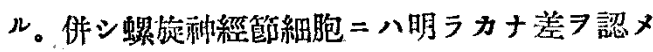
得儿。

そヨ要スル＝以上，事惯八「「アトキシール」中

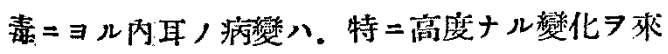

タセルモノ、膜樣部ハ別トシテ. 左右聽器二。

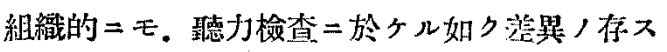
ル事ヨ知り得タノデアル。

但シ今回检查セルモノ八全䯠ノ約伴数ナルガ殘 リノモノニ就テモ检㜪フ扠へタル上. 次/機會 二更二報告セントス。

\section{表（1）聽力檢查成績（6士 例）}

\begin{tabular}{|c|c|c|c|}
\hline \multirow[b]{2}{*}{ 㯖力障碍 } & \multirow{2}{*}{$\begin{array}{l}\text { 實 羷 } \\
\text { 础物数 }\end{array}$} & \multicolumn{2}{|c|}{ 左右㖶力此䅧 } \\
\hline & & 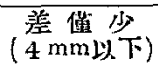 & $\mid \begin{array}{c}\text { 差著明 } \\
4 \text { min })\end{array}$ \\
\hline 輕度 & 17 & 17 & 0 \\
\hline 中等路 & 22 & 7 & 15 \\
\hline 高 度 & 13 & 0 & 13 \\
\hline 警 & 12 & & \\
\hline
\end{tabular}

表（2）組蟣的柃查成續（34例）

\begin{tabular}{|c|c|c|c|c|c|c|c|c|c|}
\hline 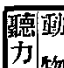 & 击 & 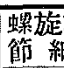 & 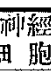 & $=\pi$ & 千器 & 脈系 & 络帶 & 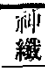 & 經 \\
\hline 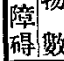 & 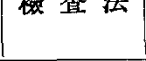 & 美螌 & 美有 & 差暂 & 羑有 & 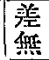 & \begin{tabular}{|l|}
$\mid$ 堶 \\
有
\end{tabular} & 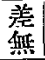 & 㘼 \\
\hline 輕 & 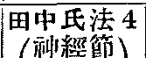 & 3 & 1 & & & & & & \\
\hline 唛 & $\begin{array}{c}\text { (細 胞 } \\
\text { 迷路全體 } 6 \\
\end{array}$ & 5 & 1 & 6 & 0 & 6 & 0 & 6 & 0 \\
\hline 中 & 田中氐法 5 & 1 & 4 & & & & & & \\
\hline Fit 14 & 逃路全體 9 & 4 & 5 & 4 & 5 & 7 & 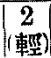 & 9 & 0 \\
\hline |高 & 田中氏法 2 & 0 & 2 & & & & & & \\
\hline 度 & 迷路全體 5 & 1 & 4 & 2 & 3 & 2 & 3 & 5 & 0 \\
\hline & 田中氏法 1 & 0 & 1 & & & & & & \\
\hline & 迷路全體 2 & 0 & 2 & 2 & 0 & 2 & 0 & 2 & 0 \\
\hline
\end{tabular}

35. 血㻺え進 /聽器二及ボス影響二 關ス儿賽驗的研究

九 阙 省三(亭 都) 1866 年 Ludwig 及 Cyon，發見七ル大動

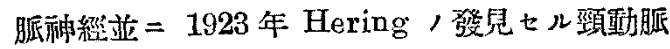

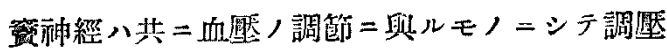

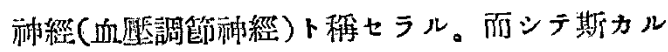

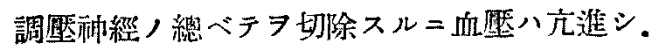


持續性ノ高血厭ジ來タス事が證明サレテ以來種

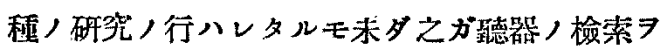
試 シシモノアラズ。卒二於テ成熟家龟ヨ用ヒテ 本實驗 =着手七ル次第ニシテ E. Koch，方法 二做ヒ先ヅ總頸動脈。內外頸動脈 $フ$ 露出シテ頸

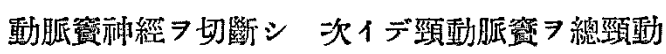
脈ヨリノ分肢部二近ク結浆シ. 更二內頸動脈 可及的頭方二於テ結禁シ。兩絬紮間 7 切斷シ。 此間 =於テ胸鏆乳頭蝣卜胸骨舌骨筋 7 縫合ス。 大動脈神經八之 7 可及的胸部二近ク切欮シ，其

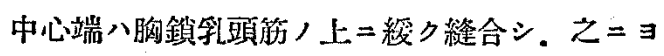
リテ兩谪經/再生ア防グ尌トセり。而シテ兩側 , 切除ハ 10-14 日間位, 閒隔 $尹$ 置テ施行セリ。 血壓测定八福田. 川口式非觀血的血壓测定器7 以テ耳杏中心動脈二於 行七像又正常血壓 7 测定シ置キ實驗後八最初4 日間八但日测定シ。 其後八每週 1 回宛測定シ持續的 =高血厘 7 惹起 セシムル事习得タり。斯カル辞物ニツイテ生體 固定後「ッニロイヂン」包埋ニヨル切片トシテ 各種, 必要ナル染色法施行,下 $=$ 之が病理組織 學的检索 7 施七り。

先ジ中耳二於テハ中耳小筋ノ横紋不明瞭トナリ 或八消失ス。賽驗長期=亘レルモノニアリテハ

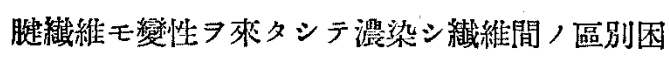
難トナル。內耳＝アリテハ先ヅ迷路骨壁二於テ ハーヴニル氏管摭大シ。膜性螺旋板二於分儿基

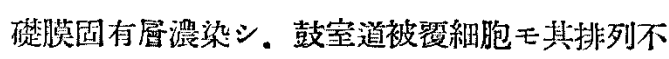
整トナリ．更二浱縮乃至捎失スルニ至ル。ライ スネル氏膜八實驗長期=亘レルモノニアリテハ 沈隆. 時二斷裂ヨ見ル。「コルチ」器ニアリテハ

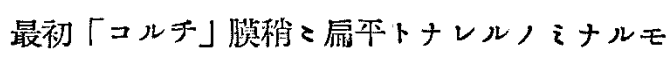
變化進メバ「コルチ」器ノ高サ泚次減ジテ毛細 胞卜支柱細胞，區別不明膫トナリ：桿細胞屈曲
シ更ニ淮メパ「コルチ」器ハ低丘戕組織塊トナ $ル ン$ 至ル。蝸牛殼神鋞

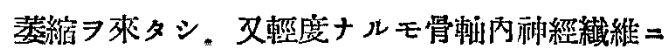

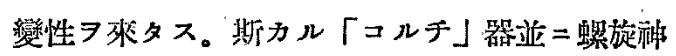
經節細胞ノ病變八一般二基礎迥轉二於テ昡著ナ

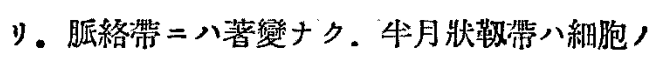

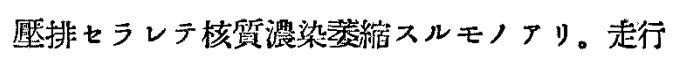

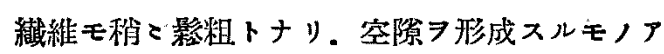
り。前庭ニアリテハー般二變化輕度ナリ。倘禾 大勘脈二於テ八管壁縮緛樣トナり或八白色，斑

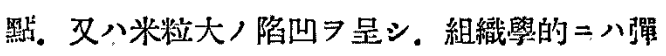
力繊維膨張シテ直線狀二延ビ繊維間, 間隔開大 せリ。筋細胞二於テモ核”祳染菱縮スルカ染色 不良トナレリ。サレド內膜ニ八肥厚习見ズ。斯 カル變化八大動胍弓並二胸部大動脈上部二方行 著シク. 血原立進 $=\Xi ル$ 機极的，變化ト見ルペ キモノナリ。斯カル大動脈管壁二於ケル變化 結果血液, 輸揆潤活 7 缺ク。至り. 動物八其末 梢部位二於テ血液，循環陪碍ヨ來タシ．從ツテ


可ナリ。而シテ前述，德器ニ於ケル所見八榮拳 障碍性聽器病變トシテー般ニ認メラレデンれ ノト概ネ一致スル所ニシテ血厴艺淮ノ結果トシ テ來タルモノト茎フルヨ得へシ。而シテ斯カル

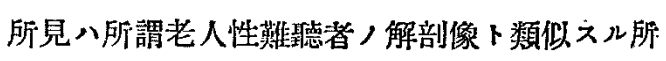
尠カラズ. 血壓立進モ亦難雅發生，因子タリ得 ベキ事ヨ思考シ.以テ本難聽成因＝關シ一新知 見ヨ加一得タルと、ト信ズル次第ナリ。

\section{類題 賓驗的高血塺及ビ動胍硬化症二}

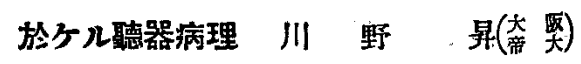

1923 年 Hering 八頸動脈筫种經ヨ發見シ之

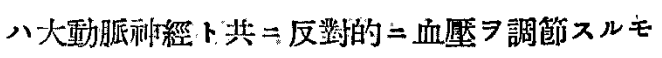

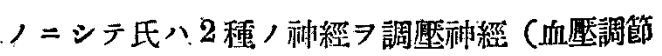

